DOI: 10.2478/linpo-2018-0012

\title{
Näen lintujen lentävän etelään 'I see birds flying south' - About an interesting case of syntactic ambiguity in Finnish
}

\author{
Robert Bielecki \\ Institute of Linguistics, Adam Mickiewicz University in Poznań \\ robertbi@amu.edu.pl
}

\begin{abstract}
Robert Bielecki. Näen lintujen lentävän etelään 'I see birds flying south' - About an interesting case of syntactic ambiguity in Finnish. The Poznan Society for the Advancement of Arts and Sciences, PL ISSN 0079-4740, pp. 55-72

An attempt is made to describe the syntactic structure of the Finnish non-attributive participial construction of the type Näen lintujen lentävän etelään 'I see birds flying south' by investigating the actual construction, and not a cognate sentence from which the construction is said to be derived. The analysis leads to the conclusion that two parts can be distinguished in the construction. The words belonging to the first part clearly determine syntactically the participle, e.g. lentävän $\leftarrow$ etelään. In the case of the words of the other group, however, there exists no syntactic test by which it would be possible to verify the direction of the relation of syntactic determination. This part of the construction is therefore to be conceived of as syntactically ambiguous, i.e. both lintujen $\leftarrow$ lentävän and lintujen $\rightarrow$ lentävän. It represents the neutralization of two structures: (i) a nominal structure (lintujen lentäminen 'birds' flying') and (ii) a nominal-verbal structure (linnut lentävät 'birds are flying'). In consequence of this fact, different syntactic interpretations of the construction do not give rise to different semantic interpretations.
\end{abstract}

Keywords: Finnish, lauseenvastike, sentence, participle, syntactic ambiguity

\section{Introduction}

What is considered dangerous by the person uttering the following English sentences?

(1) Flying planes is dangerous.

(2) Flying planes are dangerous.

In the case of sentence (1) it is unambiguously flying which is referred to as dangerous, whereas in sentence (2) it is planes.

We may, however, go on to ask what is considered dangerous by the person uttering the following sentence:

(3) Flying planes can be dangerous. 
The formulation of an answer to this question does not seem to exceed the intellectual capacity of an average English speaker. The sentence is, from this point of view, ambiguous. The answer is either (i) flying or (ii) planes. In case of the first interpretation the property dangerous (with the appropriate modal tint) is ascribed to flying. Planes are treated as supplementary information about flying (one can fly planes, rockets, paragliders, etc.). In case of the second interpretation, the property dangerous is ascribed to planes. In such a case flying is treated as supplementary information about planes (planes can be flying, standing, falling, etc.).

Nevertheless, the formulation of an answer to the question Why is it so? requires some deeper knowledge on the subject. The great Finnish linguist Esa Itkonen argues that the fact of the ambiguity of the sentence (3) Flying planes can be dangerous can be described in a systematic way by comparing it with appropriately chosen sentences which are partly identical with and partly different from it (cf. (1) and (2)). The pair of sentences (3) and (1) and the pair (3) and (2) are derived from "deep structures" representing what is perceived as identical in the respective pairs. Since the sentence (3) corresponds simultaneously to two "deep structures", it is perceived as ambiguous (Itkonen 1983: 5).

Let us take a look at this problem from a slightly different, less mystical, angle. The words which come into play in producing the ambiguity seem to be: flying, planes, can. They adopt syncretic forms in the semantic dimensions of PART OF SPEECH, CASE and NUMBER. This is corroborated by the confrontation of these three words with the words it, such; they, them; is, are serving as their non-syncretized equivalents (partly identical with and partly different from them) in the respective dimensions:

\section{PART OF SPEECH}

$\begin{array}{lll}\text { (i) flying } & \begin{array}{l}\text { noun (verbal noun) } \\ \text { adjective (gerund) }\end{array} & \text { (cf. } \text { such) }\end{array}$

CASE

(ii) planes casus rectus (cf. they)

casus obliquus (cf. them)

NUMBER

$\begin{array}{lll}\text { (iii) can } & \begin{array}{l}\text { singular } \\ \text { plural }\end{array} & \text { (cf. is) } \\ & \text { (cf. are) }\end{array}$

The noun phrase flying planes is in itself syntactically ambiguous. It represents either the configuration:

(i) noun (verbal noun) + casus obliquus $\quad$ (cf. flying them $=i$ ) or

(ii) adjective (gerund) + casus rectus $\quad$ (cf. such planes $=$ they).

In the case of the first configuration it is the verbal noun which constitutes the head (determinatum absolutum) of the phrase. In the case of the second configuration it is the 
noun planes which fulfills this function. The verbal noun belongs to the singular number. The word planes in this exact form belongs to the plural. The occurrence of the phrase flying planes in an appropriate context capable of disambiguating the number leads to disambiguation of the syntactic structure of flying planes (cf. (1) Flying planes [is], (2) Flying planes [are]).

The verb can is in itself ambiguous as regards number. In order to be disambiguated, it needs an appropriate context, for example: [It] can (singular), [They] can (plural). When put together with a phrase which itself needs a context in order to be disambiguated as regards number (cf. flying planes), it ultimately gives rise to the syntactic ambiguity of the sentence (3) Flying planes can be dangerous.

The analyzed English case is perhaps not one of the simplest. Nevertheless, it enables one to perceive the interdependence between the syntactic ambiguity and specific syntagmatic configuration of words adopting syncretic forms in the appropriate semantic dimensions. At the same time the chosen example makes us aware of how multilayered the analyzed phenomenon can be. It may involve more than two words, among which there can be distinguished appropriate subgroups interacting with other words (subgroups of words) in producing the syntactic ambiguity (cf. [[Flying $] \leftrightarrow[$ planes $]] \leftrightarrow[$ can $]$ ).

As will be shown in detail below, the so-called lauseenvastikkeet 'sentential equivalents' as in the title sentence Näen lintujen lentävän etelään 'I see birds flying south' also represent syntactically ambiguous structures, in a fashion that to the best of my knowledge has not yet been described in the literature on the subject.

\section{Delimitation problems}

The understanding of the term lauseenvastike was decisively influenced by a report of the Grammar Council (Kielioppikomitea) in 1915, in which it was defined as follows:

sellainen sane tai saneliitto, joka merkitykseltään vastaa sivulausetta mutta jolla ei ole lauseenmuotoa 'such a word form or connection of word forms which semantically corresponds to a subordinate sentence, but does not have the form of the sentence' (Wiik 1983: 270).

In accordance with this definition the bold-faced infinite participial constructions in the sentences (4a) and (5a) may be identified as lauseenvastikkeet, because both of them have their semantic analogs in the form of subordinate sentences (cf. (4b) and (5b)):

(4a) Pitkään nukkuneet lapset

syövät nyt puuroa.

'The children who were sleeping a long time are eating porridge now.'

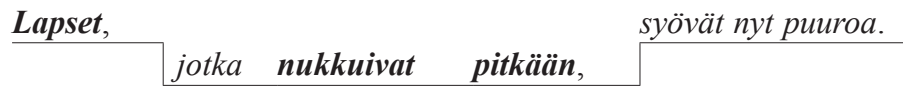

'The children who were sleeping a long time are eating porridge now.' 
(5a)

Mummo sanoo

lasten nukkuneen.

'Grandma says that the children were sleeping.'

$(5 b)$

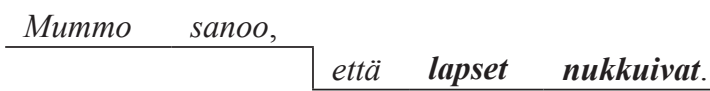

'Grandma says that the children were sleeping.'

Nevertheless, since the category of lauseenvastike was from the beginning tacitly assumed to be a Finnish peculiarity, some complementary restrictions had to be made to its definition. First of all, the constructions syntactically resembling the attributive infinite constructions of the commonly known Indo-European languages were excluded from the scope of lauseenvastike.

The essential syntactic difference between the attributive and non-attributive infinite constructions consists in their different determinational structures (cf. Bańczerowski 1980: 65-107). The determinational structure of the attributive construction in reference to the finite verb has the form of a chain with single links (words): (4a) Pitkään $\rightarrow$ nukkuneet $\rightarrow$ lapset $\leftarrow$ syövät, whereas the non-attributive construction enters into a syntactic relation with the finite verb only as a whole: (5a) \{lasten nukkuneen $\rightarrow \rightarrow$ sanoo.

The different forms of the two determinational structures are reflected in the different functions of the sentential subordinators: joka 'which' and että 'that'. The relative pronoun joka 'which' fulfills the appropriate syntactic function within the subordinate sentence. When removed, the sentence becomes defective. In turn, the conjunction että 'that' does not fulfill any syntactic function in the subordinate sentence in the same sense; it stands as if outside it. When removed, it leaves a correctly formed sentence.

In consequence, the attributive constructions are said to have one word in common with the embedding sentence (cf. (4a)), whereas the non-attributive constructions do not seem to have in this sense any word in common with the embedding sentence (cf. (5a)).

Following the shift of the definitional center of gravity onto the conjunction että 'that', there appeared other complications. Some participial constructions resembling that presented in the sentence (5a) do not seem to have sentential counterparts introduced by means of the conjunction että (cf. Penttilä 1963: 632-633; Hakulinen A. 1973: 58). Let us compare the following sentences:

(6a) Hänen on luultu

väheksyvän sellaista aihetta.

'He has been thought to underestimate such a theme.'

$$
\text { On luultu, }
$$

että hän väheksyy sellaista aihetta.

'It has been thought that he underestimates such a theme.' 
(7a) Tekijä on käsitellyt aihetta,

jonkalaista hänen on luultu väheksyvän.

'The author has handled a theme which he has been thought to underestimate.'

(7b) * Tekijä on käsitellyt aihetta,

jonkalaista on luultu, että hän väheksyy.

* 'The author has handled a theme which has been thought that he underestimates.'

The participial construction (6a) hänen _ väheksyvän sellaista aihetta has its counterpart in the form of a subordinate sentence introduced by means of että: (6b) että hän väheksyy sellaista aihetta, whereas the participial construction whose one substantival constituent fulfills the function of the relative pronoun - (7a) jonkalaista hänen _ väheksyvän - has not.

Problems also arose in connection with infinite non-attributive constructions which do have their counterparts in the form of subordinate sentences, but do not contain one of the arguments of the infinite form of the verb (being already lexicalized as an argument of the finite verb). Let us compare:

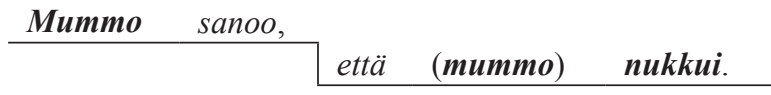

'Grandma says that she was sleeping.'

Mummo sanoo

nukkuneensa.

'Grandma says that she was sleeping.'

Muтmo lupaa,

että (mummo) nukkuu.

'Grandma promises that she will be sleeping.'

Mummo lupaa nukkua.

'Grandma promises that she will be sleeping.'

Again: the participial construction (8b) Mummo sanoo \{nukkuneensa\} belongs to the class of claimed Finnish peculiarities, whereas the infinitival construction (9b) Mummo lupaa $\{$ nukkua\} does not.

Wiik, in the article Mikä lauseenvastike on? 'What is the sentential equivalent?', concludes that probably all Finnish linguists facing such difficulties ${ }^{1}$ take advantage of the postulate of tyypeittäisyys: if a construction belongs to a type which has been previ-

${ }^{1}$ Whose other aspects, being irrelevant, will not be discussed here (cf. Lindén 1962; Siro 1964: 110-114; Vartiainen 1967; Ikola 1956, 1960: 68-75, 1971, 1978). 
ously qualified as a lauseenvastike, then the construction is a lauseenvastike (Wiik 1983: 276). It is difficult to find a more glaring example of a circular argument.

This being so, one cannot exclude the possibility that the constructions referred to in the subject literature as lauseenvastikkeet do not in fact constitute any grammatical category in Finnish (cf. Kuryłowicz 1987: 116-117). The conception of distinguishing within various construction types containing an infinite verb form a specific subclass termed lauseenvastike has therefore been ultimately abandoned by the authors of the latest academic grammar Iso suomen kielioppi 'The Great Finnish Grammar', although they admit that it is redeemed as a pedagogical term (Hakulinen A. et al. 2004: 837).

In the present article the analysis will be restricted to the non-attributive participial construction (partisiippirakenne) associated with two sets of verbs which are defined enumeratively. The first set comprises transitive verbs of perception and speaking (verba sentiendi et dicendi), e.g. ajatella 'to think', kertoa 'to tell', kuulla 'to hear', luulla 'to suppose', nähdä 'to see', tietää 'to know', uskoa 'to believe'. The second set comprises intransitive verbs of perception, e.g. kuulua 'to be heard', näkyä 'to appear', näyttää 'to appear', tuntua 'to seem', ilmetä 'to appear', osoittatutua 'to turn out', selvitä 'to turn out' (cf. Penttilä 1963: 633-635; Ikola 1978: 24-29). Let us take a look at some examples:

(10) Näen lintujen lentävän etelään.

'I see birds flying south.'

(11) Linnut tuntuvat lentäneen etelään.

'Birds seem to have flown south.'

(12) Ilmeni

varkaiden

vieneen

rahat.

'It appeared that the thieves had taken the money.'

\section{Some history}

Historical research reveals that the analyzed participial construction came into being as a result of a series of specific morphosyntactic reinterpretations and analogical alignments (cf. Ojansuu 1909: 143-158; Hakulinen L. 1979: 565-572). The contemporary relations can be most consistently explained by taking as the point of departure the following sentence type:

$\begin{array}{llll}\dagger \text { Näen } & \begin{array}{l}\text { linnu/n, } \\ \text { bird-I ACC SG }\end{array} & \begin{array}{l}\text { lentävä/n } \\ \text { flying-I ACC SG }\end{array} & \text { (linnu/n). } \\ \text { 'I see } & \text { a bird, } & \text { a flying one.' } & \\ \dagger \text { Näen } & \begin{array}{l}\text { linnu/t, } \\ \text { bird-I ACC PL }\end{array} & \begin{array}{l}\text { lentävä/t } \\ \text { flying-I ACC PL }\end{array} & \text { (linnu/t }) . \\ \text { 'I see } & \text { birds, } & \text { flying ones.' } & \end{array}$


In connection with transitive verbs (Näen) the noun which ultimately became the fundamental substantival component of the contemporary participial construction seems initially to have been the oblique argument of the governing finite verb (linnun, linnut). The participle simply fulfilled the function of an adjectival apposition, which - as befits the adjective in a broader sense in Finnish - was congruent in case and number with the noun it referred to (lentävän $\rightarrow$ linnun, lentävät $\rightarrow$ linnut).

The forms of the desinential accusative singular occurring in connection with the active voice, being largely syncretic with the forms of the genitive singular, were ultimately reinterpreted as forms of the latter. Due to the poorly developed nature of the adverbal genitive in Finnish, the noun was shifted from the direct syntactic environment of the governing finite verb to the direct syntactic environment of the infinite verb. Simultaneously, the attributive function of the participle seems to have been eliminated in such a way that its singular form became generalized and nowadays occurs independently of the number of the fundamental noun ${ }^{2}$. Let us compare:

$\begin{array}{lll}\text { Näen } & \begin{array}{l}\{\text { linnu/n } \\ \text { bird-GEN SG }\end{array} & \begin{array}{l}\text { lentävä/n }\} . \\ \text { flying-GEN SG }\end{array} \\ \text { 'I see } & \text { a bird } & \text { flying.' } \\ \text { Näen } & \{\text { lintu/j/en } & \text { lentävä/n }\} . \\ & \text { bird-PL-GEN } & \text { flying-GEN SG }\end{array}$

'I see birds flying.'

In consequence of this, there emerged in Finnish a morphosyntactically new syntagm type in which the relation between its constituents resembles that between the subject and predicate of a sentence: \{linnun lentävän\} $\approx$ että lintu lentää 'that a bird is flying', \{lintujen lentävän\} $\approx$ että linnut lentävät 'that birds are flying'.

This enabled the spread of the construction first of all in connection with verbs of speaking normally taking a direct object in the form of a subordinate sentence: Sanon, että linnut lentävät 'I say that birds are flying' $\Rightarrow$ Sanon \{lintujen lentävän\}. The occurrence of sentences of the type (12) Ilmeni \{varkaiden vieneen rahat\}, i.e. in connection with intransitive verbs, is also an indication of the action of analogy (cf. Ilmeni, että varkaat veivät rahat 'It appeared that the thieves had taken the money').

In order to complete the picture, let us compare the following pairs of sentences in which the analogy seems to have acted only upon the participial part of the construction (everywhere genitive singular!), whereas the nominal part preserves its original form:

${ }^{2}$ Interestingly enough, in analogous structures in Lithuanian the participle has also undergone a reduction of inflection by becoming the so-called padalyvis, e.g. Matau paukšti lekiant/Ø 'I see a bird flying', Matau paukščius lekiant/Ø 'I see birds flying' vs. lekiant/is paukštis 'a flying bird', lekiant/ys paukščiai 'flying birds' (Ambrazas 1979: 127, 2006: 410-411). 
(17a) $†$ Nähtiin

lintu/Ø,

tapettu/Ø

(lintu).

bird-II ACC SG

killed-II ACC SG

'One saw

a bird,

a killed one.'

(17b) $\{$ Lintu/Ø $\}$

nähtiin

$\{$ tapetu $/ \boldsymbol{n}\}$.

bird-II ACC SG

killed-GEN SG

'One saw a bird killed.'

(18a) † Näkyy

lintu/Ø,

lentävä/Ø

(lintu).

bird-NOM SG

flying-NOM SG

'There appears

a bird,

a flying one.'

(18b) $\{$ Lintu/Ø $\}$

näkyy

$\{$ lentävä/n\}.

bird-NOM SG

flying-GEN SG

'The bird

appears

to fly.'

(19a) Tiedän,

$\begin{array}{llll}\text { että pesässä } & \text { on/Ø } & \text { lintu/j/a. } \\ & & \text { be-III SG } & \text { bird-PL-PART }\end{array}$

'I know that there are birds in the nest.'

(19b) Tiedän

$$
\begin{array}{lll}
\{\text { pesässä } & \begin{array}{l}
\text { oleva/n } \\
\text { being-GEN SG }
\end{array} & \text { lintu/j/a }\} . \\
& \text { bird-PL-PART }
\end{array}
$$

'I know that there are birds in the nest.'

(20a)

\begin{tabular}{lllll} 
& että & sinu/t & on/Ø nimitetty & virkaan. \\
\cline { 2 - 5 } Näkyy, & & & \\
& & & \\
& & &
\end{tabular}

'It seems that one has nominated you to the post.'

(20b)
$\{$ Sinu/t $\} \quad n a ̈ k y y$
you-ACC
$\{$ nimitety $/ \boldsymbol{n}$
virkaan\}.

'It seems that one has nominated you to the post.'

\section{The rationale behind the participle}

Even a linguistic non-expert, after a short introspection, may understand that he is not capable of conveying verbally any state of affairs with all its details, no matter how many words he utters. The language reflects the reality, or our knowledge of the reality, in a refined way which is often referred to as diagrammatic. The language seems to signal only the contours of the reality, taking advantage of such mosaic elements which, in spite 
of their combinatorial independence, convey constant quanta of information (cf. Jakobson 1971; Anttila 1977: 11; Bogusławski 2010: 39; Bogusławski-Drzazgowska 2016: 215).

Lingual reflection (of the knowledge) of a certain part of reality takes place in sentences which realize a syntactic scheme consisting in the universally known bifurcation of the semantic content into:

(i) the subjective and

(ii) predicative part.

This bifurcation is irreducible in nature, i.e. neither of the parts of the sentence can incorporate the other. Of course, when saying both $A$ man is running and a runner we refer to a running man, but only in case of the sentence $A$ man is running do we state something about something. A runner is only an element which enters into relations of this kind.

A cursory observation of the following sentence types:

subjective part

\section{A man}

The running of a man

The beach predicative part

is running on the beach.

takes place on the beach.

is a place where a man is running.

may lead us to a hasty conclusion that every kind of element can be put in the language mosaic anywhere. In fact, such a phenomenon seems to be possible only when the whole grammatical machinery of the language is harnessed into it. The language elements in their deepest essence (in this context the notion lexical seems to be in many respects the right one) do not exhibit such omni-categoriality.

The classical division of words into such parts of speech as (i) nouns and (ii) verbs is a manifestation of this property of the language. In a minimal sentence the noun fulfills the function of subject, and the verb - the function of predicate. Sentences in which this fundamental scheme is exceeded require the appearance of more diversified word classes (cf. Heinz 1965: 53-62; Frege 1977: 53-54; Zabrocki 1980: 136).

Such labels as agent noun, verbal noun, infinitive, gerund and finally, of course, participle are customarily attached to the so-called transitory word classes between the verb and other parts of speech (noun, adverb, adjective). What is characteristic of all of them is that their forms, in opposition to the verb from which they are derived, are not as such self-sufficient in building up a minimal sentence with a noun. Even in the extreme case, i.e. when they possess as much verbal ingredient as is allowed by their definition, their forms must be complemented with a desemanticized auxiliary verb in order to become part of a sentence (cf. the English participle written in The author has written).

Against this background, what seems to be the distinctive feature of the Finnish participle, as has already been signaled, is its additional use as a syntactically free member which does not fulfill the function of attribute. 


\section{The syntax of the participial construction}

The analyzed Finnish participial construction is, analogously to the sentence, traditionally divided into two fundamental parts: (i) the subjective and (ii) the predicative part. Let us take a look at where the border between these parts is said to lie in some of the aforementioned examples:

(5a) Mummo sanoo $\{$ lasten

(6a)

(10) Näen subjective part

\{Hänen $\}$

\{lintujen

$\{$ Linnut $\}$

\{varkaiden

$\{$ Sinut $\}$

\begin{tabular}{|l|l} 
on luultu & $\begin{array}{l}\text { predicative part } \\
\text { nukkuneen }\} . \\
\{\text { väheksyvän } \\
\text { lentävän } \\
\text { tuntuvat }\end{array}$ \\
\{lentäneen \\
näkyy & $\begin{array}{l}\text { vieneen } \\
\text { \{nimitetyn }\end{array}$
\end{tabular}

sellaista aihetta\}. etelään\}. etelään\}. rahat $\}$. virkaan\}.

What strikes one in such an analysis is the ascription to the participial construction of the same semantic-syntactic structure as to the sentence from which this construction is said to be derived. Let us compare:

$\begin{array}{cccc}\text { (5b) Mummo sanoo, että } & \text { lapset } & \text { nukkuivat. } \\ & & \text { subject } & \text { predicate } \\ & & \Downarrow & \Downarrow \\ & & & \\ & & \text { (lasten } & \text { nukkuneen }\} . \\ & & \text { sabject } & \text { predicate }\end{array}$

It is difficult to find in the literature on the subject any attempt to verify this assumption by investigating not the syntactic structure of a cognate construction (here, the sentence), but the syntactic structure of the actual participial construction itself. Regrettably, the adequacy of an approach which does not admit the possibility of a change of semantic-syntactic structure between the alleged initial sentence and the participial construction may be merely a matter of chance. It seems a trivial observation that in the framework of diathetically relevant cognate constructions there can be distinguished both (i) constructions whose semantic-syntactic structure is identical and (ii) constructions whose semantic-syntactic structure is different. For example:

(i) The old woman is milking a cow. $\Rightarrow$

\{The old woman while milking a cow\} is shouting at her husband.

(ii) The old woman is milking a cow. $\Rightarrow$

\{The old woman's milking of a cow\} has been immortalized on the photo. 
There emerge in principle two parts of the Finnish non-attributive participial construction when one makes syntagmatic comparisons with diathetically relevant cognate constructions whose semantic-syntactic structure seems to be more transparent. The words belonging to the first part clearly determine syntactically the participle. In turn, in the case of the words belonging to the second part, the direction of the relation of syntactic determination is, for various reasons, obfuscated.

Among the words constituting syntactic determinanta of the participle, two types can be distinguished according to their morphosyntactic encoding. The words of the first type retain their form across all diathetically relevant cognate constructions (left column). The words of the second type retain their form except for nominalizations (right column). In such a context they acquire the forms of the genitive case. Let us compare:

(i) participle:

(10) Näen \{lintujen lentävän etelään\}. (6a) \{Hänen\} on luultu \{väheksyvän sellaista aihetta\}.

'I see birds flying south.'

'He has been thought to underestimate such a theme.'

(19b) Tiedän \{pesässä olevan lintuja\}. 'I know that there are birds in the nest.'

(12) Ilmeni \{varkaiden vieneen rahat .

'It appeared that the thieves had taken the money.'

(20b) \{Sinut $\}$ näkyy $\{$ nimitetyn virkaan $\}$.

'It seems that one has nominated you to the post.'

(ii) finite verb:

(10a) Linnut lentävät etelään.

'Birds are flying south.'

(19c) Pesässä on lintuja.

'In the nest there are birds.' (6c) Hän väheksyy sellaista aihetta.

'He underestimates such a theme.'

(12a) Varkaat veivät rahat.

'The thieves took the money.'

(20c) Sinut on nimitetty virkaan.

'One has nominated you to the post.'

(iii) verbal noun:

(10b) lintujen lentäminen etelään

'the flying of birds south'

(19d) lintujen oleminen pesässä

'the being of birds in the nest' (6d) sellaisen aiheen väheksyminen

'the underestimating of such a theme'

(12b) rahojen vieminen

'the taking of the money'

(20d) sinun nimittämisesi virkaan

'your nomination to the post'

It is easy to notice that such a pattern applies first of all to those arguments of the verb which are encoded by means of oblique cases other than the cases of direct object. These are various adverbial modifiers, e.g. etelään 'to the south' (illative), pesässä 'in the nest' (inessive). Also relevant are those arguments of the verb which are encoded in a subset of all diathetically relevant cognate constructions by means of the cases of direct 
object: the partitive (e.g. sellaista aihetta) or accusative (e.g. rahat, sinut). These are words carrying the meaning of patient in connection with the active participle (väheksyvän, vieneen) or in connection with the passive ${ }^{3}$ participle (nimitetyn) - on the condition that the finite verb is intransitive (näkyy) so that overlapping of the predicate-argument frames of the finite verb and those of the participle is excluded (for the simple reason that intransitive verbs do not take direct objects).

As far as the remaining part of the participial construction is concerned, among words encoding first of all agent and stative, but also patient in connection with the passive participle (if cases of type (20b) Sinut näkyy nimitetyn virkaan are excluded from the scope of analysis) two types of words can be distinguished according to their morphosyntactic encoding. The words of the first type acquire such a case (and number) form as to make them congruent with the finite verb as its potential subject or direct object (left column). In turn, the words of the second type acquire such a case form as to be linkable with the finite verb only via the participle (right column). Let us compare:

(5a) Mummo sanoo \{lasten nukkuneen\}.

'Grandma says that the children were sleeping.'

(6a) $\{$ Hänen $\}$ on luultu \{väheksyvän sellaista aihetta\}.

'He has been thought to underestimate such a theme.'

(11) $\{$ Linnut $\}$ tuntuvat $\{$ lentäneen etelään $\}$.

'Birds seem to have flown south.'

(20e) $\{$ Sinä $\}$ näyt $\{$ nimitetyn virkaan $\}$.

'You seem to have been nominated to the post.'

(24a) Hän ajatteli \{avainta etsityn\}.

'He thought that the key was looked for.'

(25a) $\{$ Avainta $\}$ ei ajateltu $\{$ löydetyn $\}$.

'One did not think that the key had been found.' 'One thought that the key had been found.'

At first glance, the sentences from the left column may serve as a foothold in our investigation. If in consequence of the operation of cancelation the removal of the participle were possible, then the status of the participle as the syntactic determinans of the fundamental noun of the construction would be corroborated. Nevertheless, such an operation cannot be carried out in spite of the fact that there exists in Finnish a series of correct sentences which seemingly imply that it can, for example:

(24a) Hän ajatteli avainta etsityn. $\Rightarrow$ Hän ajatteli avainta.

The sentence Hän ajatteli avainta means something slightly different than the sentence Hän ajatteli avainta etsityn. In Hän ajatteli avainta it is the key which is the object of

${ }^{3}$ The convoluted relations between the passive and impersonal voice in Finnish will not be discussed here (cf. Bielecki 2015: 112-124). 
thinking ('He was thinking about the key'), whereas in Hän ajatteli avainta etsityn that object is the irreducible fact that the key was being looked for. This latent ephemeral semantic difference becomes highlighted in sentences of the type Hän sanoi avainta etsityn 'He said that the key was looked for' which do not have counterparts without the participle: *Hän sanoi avainta. Therefore, the verb ajatella 'to think' is as if a homonym functioning in two series of verbs: in the first it takes a noun as its direct object, while in the other (like sanoa 'to say') it takes as object a syntagm consisting of a noun and a participle (genitive singular).

The essence of verbalness consists in the potency of subordination of one content to some other content. This subordination results lingually in so-called affirmation, i.e. in the stating of something (predicate) about something (subject), e.g. Linnut lentävät 'Birds are flying'.

In case of the so-called transitory de-verbal word classes such as agent noun, verbal noun, infinitive, gerund and participle, the verbal ingredient seems to be retained only to such a degree that these word classes bind the arguments of the verb with the appropriate de-verbal derivative. The direction of the relation of syntactic determination within the infinite construction may be inverted in the sense that the de-verbal derivative may constitute its determinatum absolutum (e.g. mother's killer).

As has been shown in detail above, in the case of all manifestations of the contemporary Finnish non-attributive participial construction there seems to be no accessible syntactic test by which it might be possible to verify which word - the noun encoding the patient (in connection with the passive participle except that of the type (20b) Sinut näkyy nimitetyn virkaan), agent, stative or the participle - fulfills the function of the determinatum absolutum of the construction. This being so, the hypothesis should be put forward that the relevant part of the participial construction is syntactically ambiguous, i.e. either the fundamental noun or the participle is its determinatum absolutum. Let us present both alternative syntactic structures by means of the following schemes:

Näen

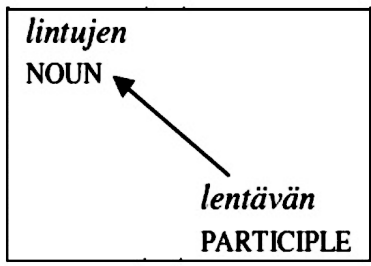

\section{Näen}

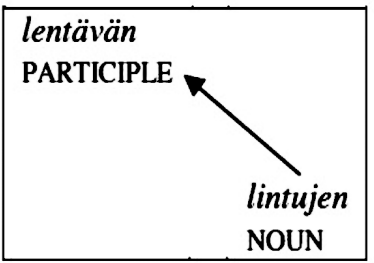




\section{What produces the syntactic ambiguity of the non-attributive participial construction in Finnish?}

As has been described in more detail in the Introduction, the syntactic ambiguity of the English sentence (3) Flying planes can be dangerous results from the co-occurrence of hierarchically organized double-sided contexts blocking the disambiguation of the morphosyntactic affiliation of the relevant words which - in consequence of this - take part in producing the said ambiguity. Let us show this by means of the following scheme:

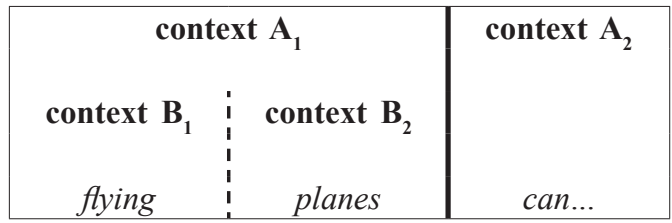

Mutatis mutandis, the hierarchic organization of these contexts in reference to the analyzed non-attributive participial construction in Finnish could be depicted as follows:

\begin{tabular}{|c:c|c|}
\hline \multicolumn{2}{|c|}{ context $\mathbf{A}_{1}$} & context $\mathbf{A}_{2}$ \\
context $\mathbf{B}_{1}$ & context $\mathbf{B}_{2}$ & \\
& & \\
lintujen & lentävän & näen... \\
\hline
\end{tabular}

The essential difference between the English construction \{flying planes\} and the Finnish \{lintujen lentävän\} is that in \{flying planes\} it is two different nominal structures that are neutralized, whereas in \{lintujen lentävän\} it is a nominal-verbal structure, characteristic of a sentence, that is neutralized with a nominal structure:

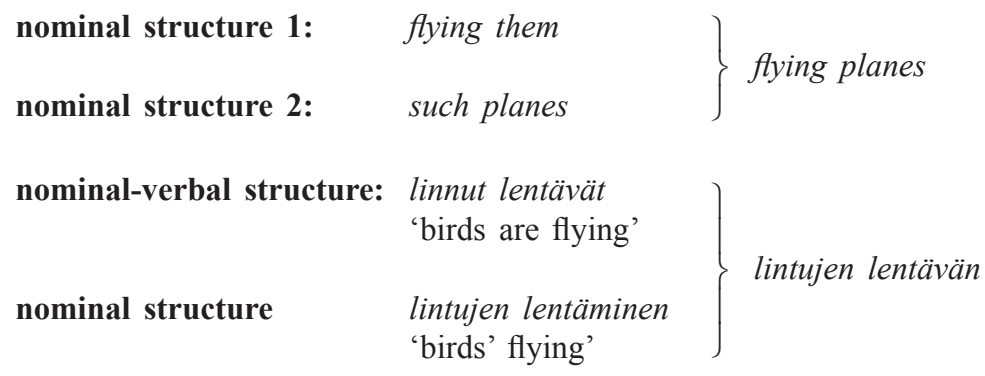

This state of affairs has far-reaching consequences for the semantics and morphosyntax of the Finnish construction.

A construction with an underlying nominal structure can be subject to the operation of cancelation, in consequence of which it becomes reduced to its determinatum absolutum: 


$$
\begin{array}{lll}
\text { flying } \leftarrow \text { them } & \Rightarrow & \text { flying } \\
\text { steh } \rightarrow \text { planes } & \Rightarrow & \text { planes } \\
\text { tintujen } \rightarrow \text { lentäminen } & \Rightarrow & \text { lentäminen }
\end{array}
$$

The fact that, for example, somebody is flying planes and not rockets is only a supplementary piece of information about the flying that is stated to be potentially dangerous. In consequence, different syntactic interpretations of the construction $\{$ flying planes $\}$ lead to the communication of semantically different messages when this construction is used in an English sentence.

A construction having the nominal-verbal structure cannot be reduced in this way. The fact that, for example, birds are flying and not falling down is not a supplementary piece of information about these birds. Instead, such a construction can be subject to a cancelation in consequence of which it becomes reduced to its first determinans:

$$
\text { tinut } \leftarrow \text { lentävät } \Rightarrow \quad \text { lentävät }
$$

Nevertheless, this can take place only on condition that its determinatum absolutum is retrievable from the context. Otherwise, it would be impossible to talk about a sentence at all. In consequence, different syntactic interpretations of the participial construction do not lead to the communication of semantically different messages when this construction is used in a Finnish sentence.

Since the participial construction as such cannot function as a lingual message, the context from which its substantival constituent may possibly be retrieved is the sentence of which the construction is a part. This is the reason why the construction appears to us at first glance as a chaotic medley of different constructions. Nevertheless, it is possible to arrange all of them according to the degree of their defectivity as regards the lexicalization of the fundamental substantival constituent, for example:

$\begin{array}{lllll}\text { (5a) } & {[\text { Mummo }} & \text { sanoo }] & \{\text { lasten } & \text { nukkuneen }\} . \\ \text { (24b) } & {[\text { Hän }} & \text { ajatteli }] & \{\text { avaimen } & \text { löydetyn }\} . \\ (24 a) & {[\text { Hän }} & \text { ajatteli }] & \{\text { avainta } & \text { etsityn }\} . \\ (24 a) & {[\text { Hän }} & \text { ajatteli } & \{\text { avainta }] & \text { etsityn }\} . \\ \text { (8b) } & {[\text { Mummo }} & \text { sanoo }] & \{\text { nukkuneensa }\} & \end{array}$

Finally, all that has been stated so far about the Finnish non-attributive participial construction should be translated into "morphosyntactic language": a "language" by means of which it is possible to show how the said syntactic ambiguity emerges from the specific syntagmatic configuration of words having syncretic forms in the appropriate semantic dimensions.

The syntactic ambiguity concerns only a part of the participial construction. As has been described in detail above, there come into play nouns belonging to the genitive, accusative, partitive and nominative cases in connection with the singular genitive form 
of the participle (except for nouns belonging to the accusative or partitive case in connection with the active participle or the passive participle linked to an appropriate intransitive finite verb of perception; cf. (20b) Sinut näkyy nimitetyn virkaan).

The words taking part in producing the analyzed syntactic ambiguity adopt syncretic forms in the semantic dimensions of CASE, FINITENESS and CONJUNCTIONALITY:

CASE

(i) lintujen

(ii) lentävän

(iii) näen casus rectus

adnominal case

FINITENESS

finite verb

verbal noun

CONJUNCTIONALITY

conjunctional verb

non-conjunctional verb (cf. linnut

(cf. lintujen

(cf. lentävät

(cf. lentäminen

'are flying')

'flying')

'birds')

'of birds')

\section{Summary and conclusions}

(cf. sanon, että

'I say that')

(cf. seuraan

'I follow')

A serious linguist should see nothing mysterious in the English sentence Flying planes can be dangerous. Its syntactic ambiguity results from the specific syntagmatic configuration of words having syncretic forms in the semantic dimensions of (i) PART OF SPEECH (flying), (ii) CASE (planes) and (iii) NUMBER (can). According to the hypothesis put forward in this paper, the phenomenon of syntactic ambiguity also characterizes Finnish sentences of the type Näen lintujen lentävän etelään 'I see birds flying south', although this seems not to have been discussed previously in the literature on the subject.

The analysis concerns the non-attributive participial construction (partisiippirakenne) linked to two sets of verbs: (i) transitive verbs of perception and speaking and (ii) intransitive verbs of perception, both defined enumeratively. This makes it possible to avoid discussion of the so-called lauseenvastikkeet 'sentential equivalents', which may not in fact constitute in Finnish any grammatical category at all.

The non-attributive participial construction came into being as a result of a series of specific morphosyntactic reinterpretations and analogical alignments, in consequence of which the noun was shifted from the direct syntactic environment of the governing finite verb to the direct syntactic environment of the participle, e.g. $\dagger$ Näen linnun [lentävän (linnun)] 'I see a bird, a flying one' $\Rightarrow$ [Näen] \{linnun lentävän\} 'I see a bird flying'. The analyzed participial construction in the historical sense may indeed be conceived of as a kind of fossilized appositional syntagm (cf. the use of the singular genitive of the participle in all its manifestations). Nevertheless, in the contemporary language it is a synchronic fact which requires a redefinition of the rationale behind the Finnish participle. 
What strikes one in the traditional approach to the analyzed construction is the lack of any attempt to verify its syntactic structure by investigating the actual participial construction itself. We have seen that in the actual participial construction, two parts can be distinguished. The words belonging to the first part clearly determine syntactically the participle, e.g. [Näen] \{lintujen lentävän $\leftarrow$ etelään\} 'I see birds flying south', \{Hänen\} [on luultu] \{väheksyvän $\leftarrow$ sellaista aihetta\} 'He has been thought to underestimate such a theme', $\{$ Sinut $\} \rightarrow$ [näkyy] $\rightarrow$ \{nimitetyn... $\}$ 'It seems that one has nominated you...'. In the case of the remaining part of the construction there is no accessible syntactic test by which it would be possible to verify which word is the determinans and which the determinatum (absolutum), e.g. (i) [Näen] \{lintujen $\leftarrow$ lentävän...\} or (ii) [Näen] \{lintujen $\rightarrow$ lentävän...\} 'I see birds flying...'. Ergo, this part of the construction is syntactically ambiguous.

When translating the findings of this paper into "morphosyntactic language" it was stated that the words taking part in producing the syntactic ambiguity of a sentence of the type Näen lintujen lentävän etelään 'I see birds flying south' are lintujen, lentävän and näen, which adopt syncretic forms in the dimensions of (i) CASE (lintujen), (ii) FINITENESS (lentävän) and (iii) CONJUNCTIONALiTy (näen). The different syntactic interpretations of the participial construction do not have semantic consequences, because it represents the neutralization of a nominal and a nominal-verbal structure, which is not reducible to its determinatum absolutum.

A mother tongue appears to its none-too-demanding user to be as unproblematic and almost as transparent as the air we breathe. He would probably consider such linguistic deliberations futile and worthless. Nevertheless, some moments of contemplation should convince him how complicated a machinery he has to deal with in the form of the language. It is enough to compare the descriptions of deeply investigated languages with the naïve and superficial descriptions of languages we hardly know, to reach the conclusion that endless linguistic discussions on the "same" problems do make sense. We hope that the present article will contribute to a better understanding of the analyzed fragment of the Finnish language and thereby to a better understanding of the nature of ethnic languages in general.

\section{Abbreviations and symbols}

$\begin{array}{ll}\leftrightarrow & \text { interacting contexts } \\ \rightarrow & \text { syntactic determination } \\ \Rightarrow & \text { transformation } \\ * & \text { incorrect } \\ / & \text { morph border } \\ {[i s]} & \text { context } \\ \neg & \text { subordinate compound sentence } \\ \{\} & \text { construction } \\ \dagger & \text { historical reconstruction }\end{array}$

$\begin{array}{ll}\text { Atsityn } & \text { cancelation } \\ \text { ACC } & \text { accusative case } \\ \text { GEN } & \text { genitive case } \\ \text { NOM } & \text { nominative case } \\ \text { Ø } & \text { morphological zero } \\ \text { PART } & \text { partitive case } \\ \text { PL } & \text { plural number } \\ \text { SG } & \text { singular number }\end{array}$




\section{References}

Ambrazas, Vytautas. 1979. Lietuviu kalbos dalyviu istorine sintaksé. Vilnius: Mokslas.

Ambrazas, Vytautas. 2006. Lietuviu kalbos istorine sintaksè. Vilnius: Lietuviu Kalbos Institutas.

Anttila, Raimo. 1977. Analogy. The Hague, Paris, New York: Mouton Publishers.

Bańczerowski, Jerzy. 1980. Systems of Semantics and Syntax. A determinational theory of language. Warsaw, Poznań: Państwowe Wydawnictwo Naukowe.

Bielecki, Robert. 2015. Finnish Case Grammar. From the Syntactic and Semantic Perspectives. Poznań: Wydawnictwo Naukowe UAM.

Bogusławski, Andrzej. 2010. Dwa studia z teorii fleksji (i inne przyczynki). Warsaw: BEL Studio.

Bogusławski, Andrzej \& Drzazgowska, Ewa. 2016. Język w refleksji teoretycznej. Przekroje historyczne. Warsaw: Katedra Lingwistyki Formalnej Uniwersytetu Warszawskiego.

Frege, Gottlob. 1977. Pisma semantyczne. Cracow: Państwowe Wydawnictwo Naukowe.

Hakulinen, Auli. 1973. Semanttisia huomioita lauseenvastikkeista. Sananjalka 15. 38-68.

Hakulinen, Auli \& Vilkuna, Maria \& Korhonen, Riitta \& Koivisto, Vesa \& Heinonen, Tarja Riitta \& Alho, Irja. 2004. Iso suomen kielioppi. Helsinki: Suomalaisen Kirjallisuuden Seura.

Hakulinen, Lauri. 1979. Suomen kielen rakenne ja kehitys. Helsinki: Otava.

Heinz, Adam. 1965. System przypadkowy języka polskiego. Kraków: Uniwersytet Jagielloński.

Ikola, Osmo. 1956. Eine finnische Partizipialkonstruktion. Ural-Altaische Jahrbücher XXVIII. 201-202.

Ikola, Osmo. 1960. Das Referat in der finnischen Sprache. Helsinki: Suomalaisen Kirjallisuuden Seura.

Ikola, Osmo. 1971. Lauseenvastikkeista ja upotetuista lauseista. Sananjalka 13. 2-51.

Ikola, Osmo. 1978. Lauseenvastikeoppia. Nykysuomen lauseenvastikkeiden ja niihin verrattavien rakenteiden selvittelyä. Helsinki: Suomalaisen Kirjallisuuden Seura.

Itkonen, Esa. 1983. Causality in Linguistic Theory. A Critical Investigation into the Philosophical and Methodological Foundations of 'Non-Autonomous' Linguistics. Bloomington: Indiana University Press.

Jakobson, Roman. 1971. Selected Writings II. Word and Language. The Hague, Paris: Mouton.

Kuryłowicz, Jerzy. 1987. Studia językoznawcze. Warsaw: Państwowe Wydawnictwo Naukowe.

Lindén, Eeva. 1962. Kolmannen persoonan possessiivisuffiksien tehtävistä suomen kirjakielessä. Virittäjä 3. 216-227.

Ojansuu, Heikki. 1909. Mikael Agricolan kielestä. Helsinki: Suomalaisen Kirjallisuuden Seura.

Penttilä, Aarni. 1963. Suomen kielioppi. Porvoo, Helsinki: Werner Söderström Osakeyhtiö.

Siro, Paavo. 1964. Suomen kielen lauseoppi. Helsinki: Tietosanakirja OY.

Vartiainen, Pentti. 1967. Verbien nominaalirakenteista. Sananjalka 9. 80-95.

Wiik, Kalevi. 1983. Mikä lauseenvastike on? In Hakulinen, Auli \& Leino, Pentti (eds.), Nykysuomen rakenne ja kehitys. Näkökulmia kielen rakenteisiin, 270-293. Pieksämäki: Suomen Kirjallisuuden Seura.

Zabrocki, Ludwik. 1980. U podstaw struktury i rozwoju języka. Warsaw, Poznań: Państwowe Wydawnictwo Naukowe. 